\author{
BEATA WOJCIECHOWSKA \\ Instytut Historii UJK, Kielce
}

\title{
O STAROŚCI I JEJ UCIĄŻLIWOŚCIACH W SPECULUM NATURALE WINCENTEGO Z BEAUVAIS (OK. 1194-1264)
}

Etapy życia ludzkiego, związane ze zmianami fizjologicznymi, były w wieloraki sposób charakteryzowane już od starożytności. Podstawowy podział wyróżniał cztery okresy: puer, adulescens, iuvenis, senex. Wejście w okres starości w większości określano między 50 a 60 rokiem życia. Herodot wskazywał 70 rok życia jako koniec ludzkiej egzystencji, zaś Arystoteles rozróżniał dojrzałość ciała, osiąganą między 30 a 35 rokiem życia i dojrzałość umysłu, która przypadała na 49 rok życia. Za początek starości uznawał wiek 63 lat, kiedy słabły siły fizyczne'. Uważał, że w podeszłym wieku ludzie szukają korzyści i stają się chciwi, a ponadto są trudniejsi w pożyciu i mniej ich cieszy obcowanie z innymi².

Starość wprawdzie charakteryzowała się osłabieniem sił fizycznych i umysłowych, ale przedstawiano ją jako wiek mądrości, przeciwstawiając młodości, zdominowanej przez namiętności. W świecie rzymskim, dochodzący do sędziwych lat, pater familias cieszył się szacunkiem w życiu prywatnym i publicznym ${ }^{3}$. Cyceron w traktacie Cato Maior de senectute stwierdzał, iż każdy okres życia ma swoje naturalne cechy, a pełną dojrzałość osiąga się na starość, która w powszechnym przekonaniu rozpoczynała się w wieku 46 lat ${ }^{4}$. Rzymski uczony i pisarz Marek Terrencjusz Warron (116-27) okres od 46 do 60 roku życia określał jako senectus, a od 60 roku życia do śmierci jako senium - późną starość połączoną z niedołęstwem i starczą niemocą ${ }^{5}$. Do tej terminologii odwołał się w swoim dziele o charakterze encyklopedycznym Izydor z Sewilli (560-636), który okres senectus sytuował między 50 a 70 rokiem życia, a senium po 70 roku życia. Etap senectus określał jako wiek powagi i przejścia od młodości do starości, zaś senium łączył ze słabością i nieudolnością ${ }^{6}$.

J. Jurkiewicz, Kiedy w starożytności rozpoczynała się starość?, „Vox Patrum” 31, (2011), t.56, s.185-197; S. Longosz, Medyczna troska o ludzi starych w starożytnym grecko-rzymskim świecie, "Vox Patrum” 31, (2011), t.56, s.199-230; T. Carp, „Puer senex” in Roman and Mediewal Thought, „Latoms” 39, 1980, s.736-739; J.A. Burrow, The Ages of Man. A Study in Medieval Writing and Thought, Oxford 1986; M. Goodich, From Birth to Old Age. The Human Life Cycle in Medieval Thought, Lanham 1989; P. Johnson, Historical Readings of Old Age and Ageing, w: Old Age from Antiquity to Past Modernity, red. P. Johnson, P. Thane, London, New York 1998, s.1-18.

2 Arystoteles, Etyka Nikomachejska, tłum. D. Gromska, Warszawa 2012, 1121b, s.150; 1156a, s.240; 1158a, s.244.

G. Minois, Historia starości. Od antyku do renesansu, tł. K. Marczewska, Warszawa 1995, s.94.

4 Cyceron, O starości, przeł. Z. Cierniakowa, w: Cyceron, Rozmowy tuskulańskie i inne pisma, Warszawa 2010, s.233, 245 .

$5 \quad$ J. Jurkiewicz, Kiedy w starożytności, s.194.

6 Sancti Isidori Hispalensis Episcopi, Etymologiarum, w: Patrologia Latina [dalej PL], ed. J.P. Migne, t.82, lib.11, c.2, Paris 1850, kol. 415-416: Sexta aetas senectus, quac nullo annorum tempore finitur; sed post quinque illas aetates quantumcumque vitae est, senectuti deputatur. Senium autem pars est ultima senectutis, dicta quod sit ter- 
Do stwierdzeń zawartych w pracy Izydora z Sewilli nawiązywał Wincenty z Beauvais, autor największej objętościowo średniowiecznej encyklopedii Speculum maius ${ }^{7}$, wybitny uczony i dominikanin, pozostający w bliskich kontaktach z członkami dynastii Kapetyngów, za panowania Ludwika IX Świętego (1226-1270). Prawdopodobnie urodził się w latach 1184-1194 w Burgundii. Nauki pobierał w Paryżu i tam wstąpił do otwartego w 1218 r. dominikańskiego klasztoru św. Jakuba. Stamtąd, około 1230 r., przeniesiono go do nowo powstałego konwentu w Beauvais, gdzie w 1246 r. został subprzeorem. Tu rozpoczął pracę nad swą monumentalną encyklopedią. Pod koniec lat 40 XIII w. oddelegowano go do cysterskiego klasztoru Mons Regalis (Royamount), który opuścił w 1260 r. Powrócił wówczas do rodzimego konwentu św. Jakuba w Paryżu, gdzie zmarł w 1264 roku. Pierwsza część monumentalnego dzieła, Speculum naturale, składająca się z 32 ksiąg, zawiera ogrom materiału dotyczącego opisu wszechświata według wątku siedmiu dni stworzenia, opartego na Księdze Rodzaju (Rdz 1,1-31). Księga XXXI została poświęcona rodzajowi ludzkiemu, a w szczególności budowie ciała, poczęciu, przyjściu na świat i poszczególnych okresach życia ludzkiego. Ostatniemu etapowi egzystencji poświęcił kilka obszernych rozdziałów, w których powoływał się bądź cytował dzieła między innymi Cycerona, Arystotelesa, Horacego, Wergiliusza, św. Hieronima, św. Ambrożego, Awicenny, Izydora z Sewilli.

Powołując się na Izydora, autora wczesnośredniowiecznego kompendium wiedzy, Wincenty starość kojarzył z ograniczeniem zdolności umysłowych, wynikającym z sędziwego wieku, który charakteryzował fizjologiczny proces stygnięcia (oziębiania) krwi. W tym zakresie dopatrywał się podobieństw między starcami a dziećmi, u których krew się jeszcze nie rozgrzała. Staruszkowie z powodu długich lat życia tracą rozum, chłopcy zaś ze swawoli i dzieciństwa nie wiedzą, co czynią. Do zalet starości zaliczał umiar w przyjemnościach, poskromienie popędu płciowego, mądrość, dojrzałość rad, rozsądek oraz gotowość na śmierć. Do negatywnych elementów starości należały zaś choroby, zniechęcenie, senność. Słabość fizyczna ciała miała wpływać na stateczność umysłu․

minus sextae aetatis. In his igitur sex spatiis philosophi vitam discripserunt humanam, in quibus mutatur et currit et ad mortis terminum pervenit.

7 O Wincentym z Beauvais zob. L. Lieser, Vinzenz von Beauvais als Kompilator und Philosoph, Lipsiae 1928; R. Weigand, Vinzenz von Beauvais. Scholastische Universalchronistik als Quelle volkssprachiger Geschichtsschreibung, Hildesheim, Olms 1991 (Germanistische texte und Studien 36); A. Fijałkowski, Ocena wartości i przydatności pracy intelektualnej w połowie XIII wieku - na podstawie pism Wincnetego z Beauvais OP. (†1264), "Studia Warmińskie" 37, 2000, s.27- 47; A. Fijałkowski, Puer eruditus. Idee edukacyjne Wincentego z Beauvais (ok. 1194-1264), Warszawa 2001, s.25-27; S. Zonenberg, Funkcja historii w zakonie dominikańskim oraz czynniki ksztattujace pamięć historyczna dominikanina w średniowieczu, „Sensus Historiae” 9, 2012/4, s.119-142.

8 Vincentius Bellovacensis, Speculum maius, t.1: Speculum naturale, "Bibliotheca mundi (...) opera et studio Benedictinorum Collegii Vedastini in alma Academia Duacensi”, Douaci ex officinal Baltazaris Belleri 1624 (reprint Graz 1964-1965), [dalej cyt. Vincentius Bellovacensis, Speculum naturale], ks. 31, c.87, kol. 2360: Senes a sensus diminutione quidam dictos esse putant: eo quod iam per vetustatem desipiant. Nam phisici stultos esse dicunt frigidioris sanguinis homines: calidi vero prudentes. Unde et senes in quibus iam friget: et pueris in quibus necdum calet minus sapiunt. hinc est quod sibi conuenit infantium etas et senum. senes enim propter nimiam etatem delirant: pueri vero per infantiam et lasciuiam ignorant quid agant: senex vero tantum generis est masculini: sicut anus feminini. Nam anus dicitur mulier sola quasi annosa: Senectus quidem multa secum et bona affert et mala. Bona scilicet quia nos a potentissimis dominis liberat. Uoluptatibus enim modum imponit: libidinis impetus frangit: sapientiam auget: maturiora consilia prebet. Mala vero: quia senium miserrimum est debilitate ac tedio. Nam subeunt morbi tristisque senectus duo nempe sunt: quibus vires corporis minuuntur: senectus videlicet ac morbus. Senectus nimirum est in bonis moribus dulcior: in consilijs vtilior: ad constantiam subeunde mortis paratior: ad reprimendas libidines fortior. Ipsaque infirmitas corporis sobrietas est mentis. Por. Sancti Isidori Hispalensis Episcopi, Etymologiarum, PL, t.82, lib.11,c.27-29, kol.418. 
Odwołując się do dzieła Cycerona „O starości”, wskazywał, że po spokojnym i dobrze spędzonym życiu może nadejść pogodna i łagodna starość, która zdobywa sobie szacunek, jeśli zachowuje swoje prawa. Cytując Cycerona podkreślał, że starość przynosi szczęście należenia do siebie samych, po latach spędzonych na przyjemnościach zmysłowych, zaspakajaniu ambicji, uczestnictwie w rywalizacji, waśniach i namiętnościach. Retorycznie zapytywał o to, co może być przyjemniejszego od obowiązków starości, której towarzyszy zamiłowanie do nauki i wiedzy. Za ukoronowanie starości uważał poważanie, które winno być owocem spędzonego uczciwie życia, a nie tylko siwych włosów i zmarszczek ${ }^{9}$. Dla wielu osób sędziwość, obok utraty rodziców, należy do najbardziej przykrych sytuacji. Starość jest bowiem smutna, pozbawiona pragnienia miłości, związana z bezczynnością, chorobami i oczekiwaniem na śmierć10. Nieudolność wiąże się ze skąpstwem, obawami, wspominaniem minionego czasu, uporem, skłonnością do narzekań, karceniem dzieci i umoralnianiem młodych ${ }^{11}$. Starość pokonuje wszystko. Przed zadaniem pytań osobie starszej należy się zastanowić, bowiem to, co wcześniej było stosowne teraz z powodu wieku staje się oskarżeniem. Trzęsący się i chwiejny starzec skłonny jest wierzyć we wszystkie nieszczęścia i naiwny sam obawia się tego, co uczynił. Chwaląc przeszłość, okazuje pogardę wobec teraźniejszości, sądząc, że tylko on jest mądry, doświadczony i za słuszne uznaje tylko to, co sam rozumie. Nie ma człowieka tak starego, któryby nie wierzył, że przeżyje rok.

Zaznaczał, że starość zjawia się niepostrzeżenie. Tak jak z chorobą, tak ze starością należy walczyć i mieć wzgląd na zdrowie. Winno się zatem stosować umiarkowane ćwiczenia, a pokarmy i napoje zażywać w celu wzmocnienia sił. Wprawdzie starców nazywają głupimi, łatwowiernymi, otępiałymi i ospałymi, ale są to wady starości gnuśnej i pozbawionej energii. I tak jak swawola i rozpusta są cechami młodzieży, ale tylko tej, która nie cieszy się dobrą opinią, tak i starcza głupota, nazywana bredzeniem, jest cechą starców o słabym umyśle, a nie wszystkich ludzi w podeszłym wieku. Wysoko należy cenić młodzieńca, w którym jest coś charakterystycznego dla starca, i starca, w którym jest coś z młodzieńca. Kto idzie tym przykładem, będzie stary ciałem, ale młody duchem ${ }^{12}$.

W kolejnym rozdziale stwierdzał, iż budowa ciała starców jest ciepła i wilgotna, a zatem wskazane jest, aby kierowali się ku temu, co rozgrzewa i nawilża. Powinni mieszkać

\footnotetext{
9 Vincentius Bellovacensis, Speculum naturale, ks.31, c.87, kol. 2360:Tullius in libro de senectute. Quiete quidem ac pure et eleganter acte etatis est placida senectus ac lenis. Nam ipsa bene acte vite ac beneficiorum multorum recordatio iocundissima est. Temeritas quoque florentis est etatis: prudentia vero senectutis. Unde qui legere vel audire antiqua voluerit: maximas res ab adolescentibus labefactas sed a senibus sustentatas ac restitutas reperit. Ceterum decorus est sermo senis: quietus et tremulus: facitque sepe ipsa sibi audientiam deserti senis compta et mitis oratio. Senectus honesta est: si ius suum retinet. O preclarum munus etatis: siquidem aufert nobis quod est in adolescentia vitiosissimum scilicet libidinem corporis. Cupidis rerum odiosum et molestum est carere. Satiatis vero et expletis iocundius est carere quam frui. Quanti illa sunt que affert senectus animum tanquam emeritis stipendijs libidinis. ambitionis: et contentionis: et amicitiarum et cupiditatum omnium secum esse: secumque. $v t$ dicitur viuere. Si vero habet aliquod tanquam pabulum studij atque doctrine nihil ociosa senectute iocundius. Apex autem senectutis est auctoritas. Unde in senatu vt quisque etate antecedit: eius sententia principatum tenet. Non tamen cani nec ruge auctoritatem repente afferre possunt: sed honeste acta superior etas fructus prebet auctoritatis extremos. Mors autem senibus sponte veniens est leuis: quod non iunenibus sicut videlicet dictum est superius. Por. M. Tulli Ciceronis, Cato Maior de senectute, 5,13; 3,9; 6,20; 11,38; 12,39; 14,47; 14,49; 17,60; 18,62.

10 Vincentius Bellovacensis, Speculum naturale, ks.31,c.88, kol.2361; Por. Vergilius, Georgicon, lib.III, 66-68,97

11 Vincentius Bellovacensis, Speculum naturale, ks.31,c.88, kol.2361; Por. Kwintus Horacjusz Flakkus, De arte poetica, 169-174, w: Tegoż, Dzieła wszystkie, t. II, tłum. J. Sękowski Wrocław, Warszawa, Kraków 1988, s.437,439.

12 Vincentius Bellovacensis, Speculum naturale, ks.31,c.88, kol.2361; Por. M.Tulli Ciceronis, Cato Maior de senectute, 7,$24 ; 11,38 ; 11,35 ; 11,36 ; 11,34 ; 11,38$.
} 
w miejscu, w którym dominuje powietrze wiosenne, a nie suche. Dla fizycznej sprawności osoby stare winny jeździć konno i ograniczyć poruszanie się piechotą. Silniejsi mogą korzystać ze spacerów, ale nie wyczerpujących. Powinni kąpać się w słodkiej i ciepłej wodzie, ale nie dłużej niż godzinę, po czym winni odpocząć. Co do pożywienia Wincenty zalecał ciepłe i wilgotne potrawy lekko strawne i szybko ustępujące z żołądka. Nakazywał wystrzeganie się pokarmów mających cierpki smak i wywołujących biegunkę, a także tych, które wywołują melancholię albo flegmę. Argumentował, iż starsze osoby powinny spożywać posiłki kilkakrotnie w ciągu dnia dla stopniowego wzmacniania się. Śniadania powinni oni konsumować między 8 a 9 rano, do godziny 11-12. Po południu wskazane były kąpiele, a po nich pokarmy rozmiękczające i rozluźniające brzuch. Wskazany był odpoczynek, unikanie stosunków płciowych i nieszczęśliwych zdarzeń losowych.

Ze względu na gromadzenie się w ciałach starców dużej ilości flegmy winni oni spożywać środki zmniejszające i wydalające flegmę. Powołując się na Hipokratesa, stwierdzał, iż w młodości żołądki wielu ludzi są miękkie i delikatne, a gdy się starzeją wówczas narząd ten ulega wysuszeniu ${ }^{13}$. Wincenty odwoływał się do koncepcji Hipokratesa, opartej na teorii o cieple i wilgoci, które mieszając się z zimnem i suchością określały zdrowie i chorobę. Elementy te były odpowiedzialne za narodziny, wzrost i proces starzenia się istot żywych. W dniu narodzin każdy otrzymywał maksymalną porcję ciepła i wilgoci, które wpływały na metaboliczne procesy wzrostu i wraz z wiekiem zanikały. Starość następowała w wyniku naturalnego procesu oziębiania się i wysuszania organizmu. Ludzie w podeszłym wieku, posiadając już mało wrodzonego ciepła i wilgoci potrzebowali mniej pokarmu i łatwiej znosili głód ${ }^{14}$.

Przywołując Awicennę, Wincenty sugerował, aby osoby starsze używały środków, które równocześnie rozgrzewają i nawilżają. Oprócz odpowiednich pokarmów proponował stosowanie kąpieli i napojów, wysypianie się i dłuższe przebywanie w łóżku, codzienne wydalanie moczu i śluzu z żołądka, aby zachować jego gładkość. Poza jazdą konną i spacerami nakazywał perfumowanie się mocnym i rozgrzewającym zapachem, a także nacieranie się olejem, szczególnie przed snem, ponieważ zabiegi te miały pobudzać męskośććc

\footnotetext{
13 Vincentius Bellovacensis, Speculum naturale, ks.31, c.89, kol. 2361-2362: Senum vero complexio quia calida et humida est hac regimine calefacienti et humectanti regi oportet. Habitet ergo in loco aere non sicco: sed simili verno. Et si debilis est virtus eius equitet: et ambulationem minuat. Qui vero fortior est vtatur deambulatione que non fatiget. Balneetur aqua dulci et calida et post vna hora quiescat. Deinde vero escas calidas et humidas digestibiles citoque a stomacho descendentes comedat: cibos autem pungitiuos et coleram generantes caueat: eos quoque qui melancoliam generant aut flegma. Pluries in die reficiatur: et hoc paulatim: quoniam eius natura non patitur nec sufficit ad digestionem multorum ciborum semel sumptorum. Prandeat hora tertia. Post meridiem balneetur: et dentur ei cibaria quedam ventrem emollientia: postea reficiatur. Coitum omnino fugiat. Et anime accidentia. Quia vero colligitur in corporibus senum flegma plurimum: oportet eos nonnunquam regi subtiliantibus et inscidentibus flegma: nec in hoc est assidue commorandum. Plurimorum quidem hominum ventres vt ait Hypocras: in iuuentute sunt molles: qui cum senuerint desiccantur eorum ventres. Et quibusdam sit econtrario.

14 S. Longosz, Medyczna troska o ludzi starych, s. 202-204.

15 Tamże, kol.2362: Summa regiminis senum est operari quod calefaciat et humectet: simul ex nutrimentis et balneis et potibus ac somno prolixo et mora multa in lecto: ex assidua quoque vrine eorum prouocatione et expulsione flegmatis ex eorum stomachis per viam intestinorum ac vesice: et vt materia lenitatis eius duret. Ex his preterea multum confert fricatio temperata in quantitate et qualitate cum oleo: deinde equitatio aut incessio. Ex aromatibus preterea aliquod bene redolens odorare debent: et proprie quod calidum temperate existit. Et oportet vt post dormitionem cum oleo inunguantur: quoniam hoc virtutem excitat animalem. Por. Libellus Avicene de viribus cordis translatus ab Arnaldo de villa nova, Venice Dionysius Bertochus1489-1490, s.99, [online]findit.library.yale.edu/ bookreader/BookRedaerDemo/index.html?oid=10943680\#page/98/mode/1up [dostęp 4.08.2015]
} 
Ciała starców powinny być pielęgnowane z zastosowaniem lekarstw wywołujących wydalanie nadmiaru humorów. Stwierdzał, że ograniczenie pracy i zmniejszenie niepokoju zapobiegają szybkiemu starzeniu się. Ci, którzy popadli w niemoc winni być całkowicie odsunięci od pracy i mieć zapewniony spokój. Należy ich wzmacniać potrawami lekkostrawnymi, zapewnić im kąpiele oraz dużo snu. Twarz i głowę winni skrapiać wonnościami. Wincenty wskazywał, aby tacy starcy umiarkowanie pili wino łagodnego gatunku, szlachetne i wytworne, lekko zmieszane z wodą. Te zabiegi pielęgnacyjne i wck azówki żywieniowe miały opóźnić bielactwo, suchoty i zapobiegać starzeniu się ciał. stwierdzał, iż nie powinna być chwalona siwizna lat, lecz obyczajów. Sugerował, że nigdy nie jest za późno na naukę i parafrazując rozważania Seneki, wskazywał, że starość zarzuca sobie lata strawione na nauce i źle spędzone życie. Te zarzuty powinna wynagrodzić praca, a także korzyści z obecnego życia. Nie należy uskarżać się na wiek, lecz wielkim wysiłkiem rekompensować stratę czasu, korzystając z życia ${ }^{16}$.

Starości towarzyszy siwizna i łysienie. Wincenty w dywagacjach na ten temat korzystał z ustaleń poczynionych przez Arystotelesa. Stwierdzał, iż siwienie w okresie starości jest sprawą indywidualną, charakterystyczną dla ludzi, choć występującą także u koni. Siwizna może pojawiać się również w wyniku choroby, czego objawem są nie tylko siwe włosy, lecz także biała skóra. Kiedy człowiek wraca do zdrowia wówczas siwe włosy wypadają i odrastają takie, jakie były wcześniej. Gdy zaś siwieją ze starości to nie bieleje powłoka skóry. Siwizna naturalna występuje z powodu ograniczenia (niedostatku) ciepłoty, która uwalnia się z ciała i nadmiaru zimna. Starość jest bowiem chłodna i wysuszona ${ }^{17}$. Siwe włosy powstają z gorąca i pokarmu, który nie jest trawiony z powodu ciepłego powietrza. Każdy bowiem proces gnilny powstaje z ciepła, nie naturalnego, lecz przypadkowego. Przyczyną siwizny włosów jest właściwość gęstego powietrza z wyziewów ziemskich. Bowiem, jeśli wyziew zamarza to tworzy się lód i siwizna. Jeśli zaś gnije i psuje się to występuje marszczenie. I z tego powodu także na ciele możemy obserwować marszczenie i siwiznę. W chorobach siwizna wywołana jest słabnięciem koloru z powodu wrzenia. Gdy wraca zdrowie powraca sprawność i włosy ciemnieją. Stąd słusznie taka słabość nazywana jest starością przypadkową, a starość słabością naturalną. Włosy skroni siwieją wcześniej, a później dopiero na pozostałej części głowy, która staje się pusta z powodu wilgoci, ponieważ nie ma w niej mózgu. W części przedgłowia jest duża wilgotność i procesy gnicia są powolne. W skroniach brakuje wilgoci, która wywoływałaby gnicie, dlatego włosy w tym miejscu siwieją

\footnotetext{
16 Vincentius Bellovacensis, Speculum naturale, ks.31, c.89, kol.2362: Seneca de naturalibus questionibus liber VII. Obijciat ergo sibi senectus annos inter studia vana consumptos: et damna etatis male exempte sarciat labor. Occupationes rescindantur patrimonij longe cura soluatur. Nam si totus animus vacet et ad contemplationem sui saltem in ipso fine respiciat: faciet ac sibimet instabit: et quotidie breuitatem temporis metiens quicquid amissum est diligenti vite presentis vsu recolliget. Faciamus igitur et quod in itinere fieri solet. Qui tardius eximus velocitate moram compensantes festinemus: magnumque opus absque etatis excusatione tractemus. Por. L. Annaei Senecae, Quaestiones naturales, 1. III, De aquis, Praefatio, 2,3,4. Wincenty powołuje się błędnie na księgę VII, zaś wskazany fragment znajduje się w ks. III.

17 Arystoteles podzielał poglądy hipokratyków i upowszechnił teorię o wrodzonym cieple i wilgoci. Od ilości i jakości ciepła i wilgoci uzależniał długość życia. Zob. Arystoteles, O młodości i starości, tłum. P. Siwek, w: Arystoteles, Krótkie rozprawy psychologiczno-biologiczne, Warszawa 1971, 467b-470b, s.114-123; Arystoteles, O rodzeniu się zwierząt, thum. P. Siwek, Warszawa 1979, 745a,s.103; Arystoteles, O dtugości i krótkości życia, tłum. P. Siwek, w: Krótkie rozprawy, 466a-b, s.107-108; M. Wilejczyk, Filozofia przyrody Arystotelesa - wokót koncepcji czterech elementów, Wrocław 2008, s. 130-140.
} 
szybciej niż w innych miejscach. U zwierząt nie występuje siwizna z powodu niewielkiego i wilgotnego mózgu, w związku z czym nie następuje osłabienie koloru z powodu wrzenia ${ }^{18}$.

Jeśli chodzi o łysienie to proces ten dotyka osobniki męskie, choć nie wszystkie, podobnie jak nie wszystkie drzewa tracą liście. Lecz liście drzewom i pióra ptakom odrastają, zaś łysym włosy nie wyrastają powtórnie. Brak włosów występuje z powodu zmiany wieku i jest nieodwracalny. Przypadki zrzucania liści i piór zachodzą cyklicznie z powodu zmiany pór roku. Przyczyną braku łysiny u zwierząt i ludzi jest mały i wilgotny mózg, i z tego powodu nie uszkadza się kolor podczas jego stopniowej utraty ze względu na wrzenie. U człowieka łysina zdarza się z powodu zmniejszenia się ciepłej i soczystej wilgoci. Włosy stają się rzadsze tam, gdzie ciepło przekracza normę i wypadają z powodu wstrzymywania się od jedzenia, lub z powodu zakażenia się wilgoci, tak jak u trędowatych. Te zjawiska występują często u mężczyzn, lecz nigdy u kobiet, urodzonych impotentów i u osób, które nie rozpoczęły współżycia płciowego, a to powodu oziębłości natury ${ }^{19}$.

Włosy niszczą się i wypadają albo z powodu materii, albo z powodu okoliczności w jakich powstają. Spowodowane jest to zużywaniem się natury. Do środków leczniczych zachowujących włosy w niezmienionym stanie należy zaliczyć te, które zawierają delikatne ciepło i styptycynę, takie jak: nasiona mirtu, balsamowca i żółci. Siwiznę zaś opóźnia wydalenie cieczy śluzowatej, stosowanie olejów wzmacniających oraz zażywanie odpowiednich środków. Należy również powstrzymywać się od spożywania mleka i potraw zawierających okruchy chleba, gęstych potraw o charakterze miazgowatym, od gotowanego zboża oraz od potraw sporządzanych na bazie miodu. Należy pić wino stare i czyste lub miód pitny. Podstawą pożywienia powinny być potrawy gotowane i pieczone ${ }^{20}$.

18 Arystoteles uważał, że włosy szczególnie intensywnie rosną w czasie choroby i w okresie starości, a siwizna wynika z braku gotowania się wilgoci oraz gnicia. Zob. Arystoteles, Zoologia, tłum.P. Siwek, Warszawa 1982, s. 99; Arystoteles, O rodzeniu się zwierząt, s.228, 231.

19 Vincentius Bellovacensis, Speculum naturale, ks.31, c.90. kol.2362-2363: In senectute canescere proprium est hominis: sed accidit et equis: non autem animalibus ceteris. Sed nec homini tantum accidit in senectute: immo etiam in infirmitate. Et tunc albescunt capilli cum albedine corij. Ipsoque homine conualescente: capilli cani cadunt ac redeunt quales prius fuerunt. Cum autem propter senectutem albescunt non albescit cum eis corium. Et huius causa est: quoniam ista infirmitas est in cute: et cum albescit cutis necessario albescunt et pili. Canicies autem naturalis est propter debilitatem caloris qui exit a corpore: et abundantiam frigoris. Nam senectus infrigidat: et corpus desiccat. Uapor autem vel cibus terrestris qui est causa et origo vilis quantum non bene digeritur: putrefit ex calore aeris continentis: et ex illo generantur cani. Omnis enim putrefactio est ex calore non naturali sed accidentali. Et hec accidit aque et terre et omnibus corporibus similibus. Causa vero albedinis canorum est: quia in omni vapore terrestri est virtus aeris crassi. Et si congeletur vapor erit ex eo glacies et canicies. Si vero putrefiat erit corrugatio. Propter hoc erunt illa duo accidentia in manifesto corporis: corrugatio scilicet et canicies. In infirmitatibus autem est canicies: quia calor debilitatur in decoctione cibi. Cumque redit sanitas: reuertitur virtus: et pili nigrescunt. Unde recte appellari potest talis infirmitas senectus accidentalis et senectus infirmitas naturalis. Pili temporum prius canescunt: posterius enim capitis vacuum est ob humiditatem: quia non est in eo cerebrum. In parte vero sincipitis est multus humor nec cito putrescit. Por. Arystoteles, Zoologia, s.99-100.

20 Vincentius Bellovacensis, Speculum naturale, ks.31, c.90, kol.2363:(...)Capilli destruuntur et minorantur aut propter causam in materia aut propter causam in re in qua nascuntur. Causa quidem in materia est aut causa eius quod eam submergit vel alterat. Aut causa paruitatis substantie prime. Paruitas quoque radicis substantie aut est propter accidens: aut quia natura consumit eam. Medicine vero conseruantes capillos ille sunt: in quibus est caliditas subtilis attractiua: et virtus stiptica: vt grana myrti et myrrha et galla: et similia. Caniciem vero retardat euacuatio flegmatici humoris. Deinde administratio medicinarum ex quibus generatur sanguis spissus laudabilis. (...).Quibusdam hominibus intempestiue cani solent nasci: ceteris autem tardari complexionis sue causa. De his quidem que caniciem tardari faciunt est:vt de trifera minori frequenter in mane sumatur. Abstinere enim conuenit a lacte et a cibis habentibus micas panis admixtas: et a pultibus que multum sunt spisse: et a frumento cocto: et ab his que conficiuntur ex melle et a potu aque multe. Uinumque vetus ac purum modice bibendum est: vel hydromel. Maior autem pars eorum quibus nutrimentum sit Kalaie sint et assature. Por. Libellus Avicene de viribus cordis 
Wincenty uznawał starość za naturalny okres w życiu człowieka i scharakteryzował ją od strony filozoficzno-medycznej. W kolejnych rozdziałach łączył wypowiedzi wybranych autorytetów antycznych, arabskich i chrześcijańskich, wpisując się w tradycję intelektualną swojej epoki. Wybierał te fragmenty dzieł i tekstów, które uważał za ważne i ukazujące różne aspekty starości. W swych rozważaniach starał się wyważyć wady i zalety starości, wiele kwestii wyjaśniając i udzielając konkretnych wskazówek. Stwierdzał, iż słabości i dolegliwości towarzyszące podeszłym latom są równoważone przez walor mądrości, roztropności i doświadczenia. Odwołując się do ustaleń medycyny greckiej, łączył starość z utratą wrodzonego ciepła i wysuszaniem organizmu. W związku z tym udzielał porad dotyczących żywienia, wzmacniania sił fizycznych i umysłowych. Podkreślał, że starość należy przyjmować jak zrządzenie losu. Nie należy z tego powodu popadać w rozpacz i pogrążać się w beznadziejności, ale poprzez mądre życie przygotować się do śmierci.

\section{Senility and its inconveniences according to Speculum naturale by Vincent of Beauvais Summary}

The stages of human life and the corresponding physiological changes have been described in many ways since ancient times. Although old age was characterized by physical and mental weakening (senility), it was portrayed as an age of wisdom which contrasted youth dominated by passions. Vincent of Beauvais devoted a few extensive chapters of Speculum naturale to the last stage of life and cited works of Cicero, Aristotle, Horace, Virgil, St. Jerome, St. Ambrose, Avicenna, Isidore of Seville, which gave him a place in the intellectual tradition of his era. According to him, the advantages of old age were moderation in pleasures, lower libido, wisdom, maturity of advice, common sense and reconciliation to death. The negative aspects of senility were diseases, discouragement and drowsiness. The physical weakness of the body affected the stability of mind. Vincent recognized old age as a natural period in human life and characterized it from the philosophical and medical points of view. He chose those pieces of writings which he considered important and representing different aspects of old age. He advised on nutrition, strengthening of the body and mental energy. Vincent emphasized that old age should be considered as fate. Therefore, there is no reason to fall in despair and wallow in hopelessness, but prepare for death through a wise life.

Keywords: senility, physiological changes, human life

Nota o Autorze: dr hab. Beata Wojciechowska prof. UJK, historyk, mediewistka zajmująca się religijnością, historią prawa kanonicznego oraz medycyną średniowieczną.

translatus ab Arnaldo de villa nova, Venice Dionysius Bertochus 1489-1490,s.711-712,[online] findit.library.yale. edu/bookreader/BookRedaerDemo/index.html?oid=10943680\#page/98/mode/1up, [dostęp 4.08.2015] 